\title{
PENGGUNAAN MODEL HOMESCHOOLING DALAM PEMBELAJARAN PAK DI PKBM WESLEY PELITA BANGSA SCHOOL (WPBS)
}

\author{
Hasan Nadir Giawa \\ Desi Sianipar \\ Universitas Kristen Indonesia \\ giawanadir86@gmail.com \\ desi.sianipar07@gmail.com
}

\begin{abstract}
Abstrak
Tujuan penelitian ini adalah untuk mengetahui apa yang dimaksud dengan homeschooling, model homeschooling dan penggunaan model homeschooling dalam pembelajaran PAK di Pusat Kegiatan Belajar Masyarakat (PKBM) Wesley Pelita Bangsa School (WPBS) Pluit-Jakarta. Teknik pengumpulan data yang digunakan dalam penelitian ini adalah wawancara, observasi dan dokumentasi. Jumlah populasi dalam penelitian ini 67 orang informan, sedangkan yang menjadi sampel penelitian berjumlah 16 orang yang terdiri dari 4 orang guru, 6 orang tua dan 6 orang siswa/i dengan kriteria mereka terlibat secara langsung dalam kegiatan homeschooling. Penentuan sampel ini berdasarkan pada tujuan penelitian.

Hasil penelitian menunjukkan bahwa guru, orang tua dan siswa/i memahami homeschooling sebagai sekolah rumah tetapi pemahaman mereka tentang model-model homeschooling kurang memadai, rata-rata mengenal dua model homeschooling. Ini membuktikan bahwa kurangnya informasi tentang homeschooling ini membuat banyak orang tidak memahaminya. Selanjutnya penggunaan model homeschooling dalam pembelajaran PAK menunjukkan hal yang positif di mana dalam setiap anak sebelum memulai pembelajaran setiap hari diwajibkan untuk menghafal ayat-ayat Alkitab, saat teduh dan doa bersama di dalam kelas.

Mengingat pentingnya homeschooling, maka perlu ada solusi yang segera dilakukan yaitu mengadakan seminar dan pelatihan kepada guru dan orang tua supaya lebih memahami pentingnya homeschooling dan model-model homeschooling. Dengan demikian homeschooling menjadi sebuah pilihan alternatif dan pertimbangan bagi orang tua untuk kebutuhan pendidikan anak.
\end{abstract}

Kata kunci: Model homeschooling, pembelajaran PAK 


\section{Pendahuluan}

Pendidikan yang diselenggarakan di Indonesia merupakan realisasi dari salah satu tujuan didirikannya Negara Kesatuan Republik Indonesia (NKRI), yakni mencerdaskan kehidupan bangsa. Pendidikan dirumuskan sebagai ilmu yang mempelajari hubungan timbal balik antara peserta didik dengan pendidik dalam berbagai situasi untuk mencapai tujuan secara optimal yang berkaitan dengan kehidupan berbudaya dan mandiri yang lebih baik dimasa depan. Pendidikan merupakan suatu proses perubahan perilaku yang dinyatakan dalam bentuk penguasaan, penggunaan dan penilaian terhadap sikap, pengetahuan dan ketrampilan dasar. ${ }^{1}$

Pendidikan berasal dari kata didik, yaitu memelihara dan memberi latihan untuk meningkatkan akhlak dan kecerdasan pikiran. Pendidikan akhlak dapat juga diartikan sebagai perbuatan, hal, cara mendidik, pengetahuan, latihanlatihan badan, batin dan jasmani. Pendidikan juga adalah proses membimbing manusia dari kegelapan, kebodohan, dan kemiskinan ${ }^{2}$. Dalam arti luas, pendidikan baik formal maupun yang informal meliputi segala hal yang memperluas pengetahuan manusia tentang dirinya sendiri.

Saat ini homeschooling sedang tren di tanah air di mana banyak masyarakat memanfaatkan model belajar ini karena banyak anak mengeluh tidak cocok dengan model belajar di sekolah formal, mereka mengeluh karena mata pelajaran

\footnotetext{
${ }^{1}$ Tim Pengembang Ilmu Pendidikan FIPUPI, Ilmu dan Aplikasi Pendidikan, bagian 4 pendidikan lintas bidang, Bangung: Garsindo, 2009, 315

2 Tim Pengembang Ilmu Pendidikan FIPUPI, Ilmu dan Aplikasi Pendidikan, bagian 3 ilmu pendidikan teoritis Bandung: Garsindo, 2007, 20.
}

yang banyak. Banyaknya tugas di rumah (PR) bisa membuat anak stress dan menyita waktunya untuk bermain dan bersosialisasi dengan lingkungan sekitar, dan suasana belajar menjadi menjenuhkan. Jika anak mengeluh dan merasa tidak cocok dengan lembaga pendidikan formal di sekolahnya, maka orang tua harus memberikan alternatif pendidikan lain, yakni dengan homeschooling. Setiap orang tua pasti menginginkan anaknya dapat berkembang optimal dan menikmati masa pendidikannya. Namun pada kenyataannya, ada orang tua merasa lembaga pendidikan yang ada, tidak lagi dapat memberikan pendidikan terbaik bagi anaknya. Menurut Reni AkbarHawadi, pakar psikologi pendidikan anak, sebagaimana dikutip oleh Windya Novita, mengatakan bahwa homeschooling dapat menjadi salah satu pilihan. Homeschooling memungkinkan anak memperoleh kurikulum spesifik dan teknik mengajar yang sesuai dengan kebutuhan anak. $^{3}$

Sistem belajar di sekolah formal menurut sebagian orang tua justru menambah beban dan membuat anak merasa bosan karena ada proses pengulangan (repetisi) mata pelajaran. Sekolah formal juga harus mencapai target pencapaian yang hanya mementingkan nilai kognitif, sehingga anak sering mempertaruhkan apapun demi memperoleh nilai yang tinggi dengan cara yang curang, misalnya menyontek saat ujian, membeli soal-soal ujian demi sebuah nilai kelulusan. Cara belajar seperti ini justru menghambat cara berpikir positif dan cara menghadapi masalah kehidupannya di

\footnotetext{
${ }^{3}$ Windya Novita, Serba-serbi Anak:Yang Perlu Diketahui Seputar Anak dari dalam Kandungan Hingga Masa Sekolah (Jakarta: Gramedia, 2007), 190.
} 
masa yang akan datang, mereka cenderung mencari jalan pintas dalam menyelesaikan persoalan. ${ }^{4}$

Salah satu sistem pendidikan nonformal yang paling sering dijadikan pilihan adalah homeschooling. Walaupun disebut homeschooling, kegiatan belajar mengajar tidak harus diadakan di rumah. Beberapa kurikulum homeschooling bertempat di sekolah seperti pada umumnya. Homeschooling bukanlah pelarian untuk anak-anak yang gagal di pendidikan formal dan bukan juga hanya untuk anak yang berkebutuhan khusus tetapi homeschooling merupakan bentuk pendidikan yang memberi kebebasan bagi anak untuk berkreasi sesuai dengan talenta, keunikan dan kemampuan yang dimilikinya. Pada kenyataannya, kita dapat menemukan anak-anak cerdas yang disekolahkan di homeschooling. ${ }^{5}$

Homeschooling merupakan model belajar di rumah yang jelas berbeda dengan lembaga pendidikan formal di sekolah. Menurut Seto Mulyadi yang dikutip oleh Windya Novita, mengatakan bahwa bagi anak, sekolah sesungguhnya adalah di rumah, hanya saja orang tua jarang dapat menyediakan waktu khusus untuk mengajarkan suatu pelajaran atau studi tertentu. Homeschooling merupakan kegiatan belajar di rumah yang terprogram, terstruktur dan sistematis dan tetap mengacu pada kurikulum standar. Selain itu, setiap periode, anak juga menjalani tes tertentu untuk mengetahui sejauh mana prestasi belajar yang sudah dicapai dan untuk mendapatkan ijazah seperti di sekolah

\footnotetext{
${ }^{4}$ Wawancara non-formal penulis dengan orangtua siswa sekolah Wesley Pelita Bangsa School pada tanggal 10 Mei 2016

${ }^{5}$ Wawancara non-formal penulis dengan Kepala sekolah Wesley Pelita Bangsa School pada tanggal 12 Juni 2016
}

formal bisa melalui ujian persamaan yang dilakukan Departemen Pendidikan dan Kebudayaan (Depdikbud). ${ }^{6}$

Pengertian umum homeschooling adalah model pendidikan di mana sebuah keluarga memilih untuk bertanggung jawab sendiri atas pendidikan anakanaknya dan mendidik anaknya dengan menggunakan rumah sebagai basis pendidikannya. ${ }^{7}$ Pada homeschooling, orang tua bertanggung jawab sepenuhnya atas proses pendidikan anak, sementara pada sekolah reguler tanggung jawab itu didelegasikan kepada guru dan sistem sekolah. Walaupun orang tua menjadi penanggung jawab utama homeschooling, tetapi pendidikan homeschooling tidak hanya dan tidak harus dilakukan oleh orang tua. Selain mengajar sendiri, orang tua dapat mengundang guru privat, mendaftarkan anak pada kursus, melibatkan anak-anak pada proses magang, dan sebagainya ${ }^{8}$.

Kata homeschooling berasal dari bahasa Inggris yang berarti sekolah rumah. Istilah ini dipakai secara resmi oleh Departemen Pendidikan Nasional (Depdiknas) untuk menyebutkan homeschooling. Selain sekolah rumah, homeschooling kadang-kadang juga diterjemahkan dengan istilah sekolah mandiri. Homeschooling merupakan model pendidikan alternatif selain di sekolah. ${ }^{9}$

Penggunaan metode homeschooling dalam pembelajaran PAK sangatlah efektif karena PAK basis

\footnotetext{
${ }^{6}$ Ibid., 191.

7 Sumardiono, Homeschooling A Leap for better Learning, Lompatan Cara Belajar (Jakarta: Gramedia 2007), 4.

${ }^{8}$ Sumardiono, Apa itu Homeschooling, 35 Gagasan Pendidikan Berbasis Keluarga (Jakarta: Panda Media, 2014), 163.

${ }^{9}$ Sumardiono, Homeschooling A Leap for better Learning,...3-4.
} 
utamanya adalah keluarga. Menurut Bushnell yang dikutip oleh Thomas $\mathrm{H}$. Groome, mengatakan bahwa keluarga merupakan sumber asuhan Kristen yang utama dan para orang tua harus menjaga supaya suasana keluarga benar-benar kristiani karena anak-anak tumbuh dalam iman melalui proses induksi alamiah dan harus menjadi fondasi bagi seluruh usaha pendidikan berikutnya. ${ }^{10}$ Baik homeschooling maupun PAK sama-sama menekankan rumah sebagai basis utama dalam proses pembelajaran. Dengan demikian, penggunaan model homeschooling dalam pembelajaran PAK sangatlah penting untuk diterapkan dalam kehidupan keluarga.

Pendidikan di rumah bukanlah hal yang baru. Sebelum ada sistem pendidikan modern (sekolah) sebagaimana yang dikenal pada saat ini, pendidikan dilakukan berbasis rumah. Sistem magang adalah model pendidikan yang sangat dikenal oleh masyarakat. Demikian pun dengan belajar otodidak yang sampai sekarang masih dilakukan. Selain itu, para bangsawan zaman dahulu biasa mengundang guru-guru privat untuk mengajar anak-anaknya. Itulah jejak homeschooling pada masa dahulu. Sejak perkembangan revolusi industri, terjadi proses sistematisasi pendidikan dan proses belajar. Perkembangan filsafat dan ilmu pengetahuan serta usaha untuk memaksimalkan proses pembelajaran selama berabad-abad menghasilkan sebuah evolusi sistem pendidikan yang kemudian kita kenal sebagai sekolah. ${ }^{11}$

${ }^{10}$ Thomas H. Groome, Christian Religious Education-Pendidikan Agama Kristen: Berbagi Cerita dan Visi Kita (Jakarta: BPK. Gunung Mulia, 2010), 172.

${ }^{11}$ Sumardiono, Homeschooling A Leap for better Learning, Lompatan Cara Belajar (Jakarta: Gramedia 2007), 19.
Di Amerika Serikat, gelombang pertama homeschooling terjadi pada era 1960-an. Pada masa ini, mulai muncul pemikiran bahwa anak-anak belajar lebih baik jika tanpa instruksi sebagaimana di sekolah. $^{12}$ Banyak pemikiran yang muncul mempertanyakan efektivitas sekolah dalam menjalankan fungsi pendidikan. Pada akhir 1970-an, John Candlwel Holt, sebagaimana diceritakan oleh Sumardiono, bahwa dia telah menerbitkan surat kabar "Growing Without School" yang menjadi sistem pendukung homeschooling pada masa itu. Setelah itu, homeschooling terus berkembang dengan berbagai alasan. Selain karena alasan keyakinan (beliefs), pertumbuhan homeschooling juga banyak dipicu oleh ketidakpuasan atas sistem pendidikan di sekolah. Keadaan pergaulan sosial di sekolah yang tidak sehat juga memberikan kontribusi terhadap pertumbuhan homeschooling. ${ }^{13}$

Negara Indonesia melalui berbagai perundang-undangan yang ada telah menjamin hak warganegara untuk mendapatkan pendidikan, termasuk di dalamnya homeschooling sebagai salah satu model mendapatkan pendidikan bagi anak. Hal ini dapat dilihat pada UU no 20/2003 tentang Sistem Pendidikan Nasional pasal 27 telah menjamin eksistensi dan legalitas pendidikan informal sebagai bagian integral dalam sistem pendidikan yang berlaku di Indonesia. Pada bagian VI dimuat ketentuan tentang pendidikan Informal. Pada pasal 27 ayat 1-3 dinyatakan kegiatan pendidikan informal. ${ }^{14}$ Pasal 27 ayat 1-3 dikutip secara lengkap dibawah

\footnotetext{
12 Ibid., 21.

13 Ibid., 22.

${ }^{14}$ Undang-Undang Republik Indonesia
} Nomor 20 Tahun 2003 Tentang Sistem Pendidikan Nasional. 
ini:

(1) Kegiatan pendidikan informal yang dilakukan oleh keluarga dan lingkungan berbentuk kegiatan belajar secara mandiri. (2) Hasil pendidikan sebagaimana dimaksud dalam ayat (1) diakui sama dengan pendidikan formal dan nonformal setelah peserta didik lulus ujian sesuai dengan standar nasional pendidikan. (3) Ketentuan mengenai pengakuan hasil pendidikan informal sebagaimana dimaksud dalam ayat (2) diatur lebih lanjut dengan Peraturan Pemerintah.

Keunggulan dari sistem homeschooling adalah lebih fokus pada individu. Anak-anak memulai pelajaran pada tingkat yang sesuai dengan kebutuhan mereka, sehingga mereka bisa lebih cepat sesuai dengan tingkat kemampuan mereka. Dengan demikian, fokusnya adalah pembelajaran, dan waktu bukanlah patokan. Anak-anak akan mampu menguasai setiap topik dengan maksimal dan bukan hanya menghafal karena tuntutan. ${ }^{15}$ Hal ini hanya dapat dicapai ketika anak diberi kebebasan untuk belajar sesuai dengan kapasitas dan kemampuan yang dia miliki. Suasana homeschooling tentu akan berbeda dengan sekolah formal. Biasanya di homeschooling, dalam satu kelas hanya ada seorang anak dan seorang guru. Ini tentu bermanfaat bagi anak karena perbandingan pengajar dan murid yang lebih rendah dibandingkan dengan sekolah biasa. Dengan begitu, setiap murid akan mendapatkan perhatian yang lebih besar dari guru. Tekanan ketika anak tidak dibandingkan dengan anak lain akan berkurang, karena tidak ada keharusan mengikuti standar

\footnotetext{
${ }^{15}$ Hasil pengamatan sementara penulis dengan Wesley Pelita Bangsa School dari JuniDesember 2016.
}

yang berlaku. Jika anak tidak tertekan, kemungkinan mereka akan dapat belajar dengan lebih baik dan tidak ada pelabelan anak 'bodoh' atau 'tidak berguna' karena patokan perbandingan anak adalah dirinya sendiri dan bukan orang lain. Oleh karena itu, penggunaan model homeschooling dalam pembelajaran PAK di Indonesia dapat menjadi alternatif untuk pendidikan, dan dapat membantu anak untuk mencapai tujuan pendidikan secara optimal.

Munculnya homeschooling merupakan bentuk kritik terhadap realita-realita negatif terutama ketidak efektifan sebagian besar proses belajar di sekolah formal, serta merupakan alternatif proses pendidikan yang memberikan peluang sebesar-besarnya kepada anak untuk mengembangkan diri dan memiliki motivasi belajar secara mandiri.

Salah satu dari banyaknya homeschooling yang ada, yang dipilih dalam penelitian ini yaitu Sekolah Wesley Pelita Bangsa School PluitJakarta Utara. Sekolah Wasley Pelita Bangsa School Pluit-Jakarta Utara, merupakan homeschooling yang telah dirancang dan disesuaikan dengan kurikulum nasional. Di mana metode belajar dan panduan pengajaran yang mementingkan nilai-nilai kekristenan, ini kita bisa lihat di setiap modul yang ada selalu disertai dengan kutipan ayat-ayat Firmna Tuhan.

Berdasarkan gambaran yang telah diuraikan di atas, penulis terdorong untuk melakukan penelitian terhadap permasalahan tersebut dengan judul: Penggunaan Model Homeschooling Dalam Pembelajarkan PAK di PKBM Wesley Pelita Bangsa School (WPBS)Pluit Jakarta Utara.

\section{Tinjauan Teoritis}

Kata homeschooling berasal dari 
bahasa Inggris adalah sekolah rumah. Istilah ini dipakai secara resmi oleh Departemen Pendidikan Nasional (Depdiknas) untuk menyebutkan homeschooling. Selain sekolah rumah, homeschooling kadangkala juga diterjemahkan dengan istilah sekolah mandiri. ${ }^{16}$ Menurut Abdurrahman, yang dikutip oleh Jamal Ma'mur Asmani, mengatakan bahwa selain homeschooling ada istilah home education atau home based learning yang digunakan untuk maksud yang sama yaitu model alternatif belajar selain di sekolah. ${ }^{17}$ Menurut Sumardiono, homeschooling adalah model pendidikan di mana sebuah keluarga memilih untuk bertanggung jawab sendiri atas pendidikan anaknya dan mendidiknya dengan menggunakan rumah sebagai basis pendidikannya. ${ }^{18}$ Pada dasarnya, setiap orang tua di dunia memiliki bakat dan kemampuan alami sebagai guru yang sangat profesional bagi putraputrinya sendiri. ${ }^{19}$ Dari pendapat di atas, dapat ditarik kesimpulan bahwa homeschooling merupakan model alternatif belajar di rumah selain di sekolah, di mana orang tua menjadi guru dan bertanggungjawab penuh atas pendidikan anaknya. Senada dengan pendapat pakar pendidikan moral, Robert Coles, sebagaimana dikutip langsung oleh B.S. Sijabat, dalam bukunya, mengakui bahwa keluarga merupakan lingkungan primer atau

16 Sumardiono, Ibid., 3.

17 Jamal Ma'mur Asmani, Buku Pinter

Homeschooling: Menjadi Kegiatan Belajar

Lebih Nyaman dan Mengena (Jogjakarta:

FlashBooks, 2012), 46.

18 Sumardiono, Ibid., 4.

${ }^{19}$ Seto Mulyadi, Homeschooling Keluarga Kak Seto: Mudah, Murah, Meriah, dan Direstui Pemerintah (Bandung: Kaifa, 2007), 114. terdepan dalam membentuk kecerdasan moral anak. ${ }^{20}$

Homeschooling adalah sebuah tindakan proaktif untuk ikut campur di dalam pendidikan anak dan bertanggung jawab untuk memberikan sebuah kecintaan terhadap belajar. $^{21}$ Bisa dikatakan bahwa homeschooling merupakan sebuah sekolah alternatif yang mencoba menempatkan anak sebagai subjek belajar dan menyekolahkan anak di rumah secara penuh. Pemahaman ini mungkin tidak semua orang bisa terima, karena banyak orang tua menyekolahkan anaknya di sekolah umum. Tetapi menyekolahkan anak dengan sistem homeschooling sama saja tidak sekolah.

Menurut Direktur Pendidikan Kesetaraan Departemen Pendidikan Nasional (Depdiknas), Ella Yulaelawati, dalam bukunya Jamal Ma'mur Asmani, mengatakan bahwa homeschooling merupakan proses layanan pendidikan yang secara sadar, teratur, dan terarah dilakukan oleh orang tua atau keluarga dan proses belajar mengajar pun berlangsung dalam suasana yang kondusif. ${ }^{22}$ Menurut Seto Mulyadi, sebagaimana ditulis oleh Mutiara Dwi R, mengatakan bahwa secara etimologis homeschooling adalah sekolah yang diadakan di rumah. Namun secara hakiki, homeschooling adalah alternatif yang menempatkan anak-anak sebagai subjek melalui pendidikan secara at home. Walaupun namanya homeschooling, tetapi anak tidak hanya belajar di rumah, melainkan bisa belajar di mana saja asalkan situasi dan

${ }^{20}$ B.S. Sijabat, Membesarkan Anak dengan Kreatif (Yogyakarta: Andi, 2012), 19.

${ }^{21}$ Holy Setyowati Sie, Homeschooling

Creating The Best of Me (Jakarta: Kompas Gramedia, 2010), 1.

22 Jamal Ma'mur Asmani, Ibid., 47. 
kondisinya nyaman dan menyenangkan seperti di rumah. Jam belajarnya pun fleksibel mulai bangun tidur sampai tidur lagi. ${ }^{23}$ Jadi, homeschooling merupakan model pembelajaran yang sangat memperhatikan keadaan anak yang ingin belajar. Dengan cara belajar yang fleksibel, akan membuat anak merasa senang tanpa paksaan, sehingga hasil yang didapatkan lebih optimal. Model pembelajran ini juga melatih anak untuk belajar mandiri dan menumbuhkan rasa cinta akan belajar. Semua itu disesuaikan dengan kondisi dan keadaan anak, sehingga akan muncul perasaan menyenangkan dan nyaman dalam belajar. Dengan demikian anak juga dijadikan subjek dalam pembelajarannya, dan tidak lupa bahwa dalam homeschooling orang tua berperan sebagai penanggung jawab utama. Para ahli psikologi dan pendidikan anak pada umumnya menyatakan bahwa lingkungan yang paling banyak mempengaruhi pemebntukan watak, iman, dan tata nilai anak adalah keluarga. $^{24}$ Yulia singgih D. Gunarsa mengatakan bahwa, keluarga tidak hanya berfungsi sebagai penerus keturunan tetapi merupakan sumber pendidikan utama, karena segala pengetahuan dan kecerdasan intelektual manusia diperoleh pertama-tama dari orang tua dan anggota keluarga sendiri. ${ }^{25}$

Peranan orang tua sebagai pengajar utama bagi anaknya bukanlah hal yang baru, hal ini bisa kita lihat dalam kitab Perjanjian Lama ketika Musa

${ }^{23}$ Mutiara Dwi R, Belajar tidak harus di Sekolah formal, Tabloid Mom\&Kiddie, edisi 14, tahun 1, 12-25 Maret 2007, hal. 14.

${ }^{24}$ B.S. Sijabat, Membesarkan Anak dengan Kreatif, ..., 19.

25 Yulia singgih D. Gunarsa, Singgih D. Gunarsa, Psikologi Untuk Keluarga (Jakarta: BPK Gunung Mulia, 2012), 1. mengumpulkan bangsa Israel di sepanjang sungai Yordan, Musa mengajarkan bangsa Isreal sebelum mereka sampai ke tanah perjanjian, bahwa yang menjadi pengajar utama untuk anaknya adalah orang tuanya sendiri. ${ }^{26}$ Hal ini terdapat dalam Ulangan 6:6-7 yang dikutip secara langsung dari alkitab dibawah ini:

"Apa yang kuperintahkan kepadamu hari ini haruslah engkau perhatian. Haruslah engkau mengajarkannya berulang-ulang kepada anak-anakmu dan membicarakannya apabila engkau duduk di rumahmu, apabila engkau sedang dalam perjalanan, apabila engkau berbaring dan apabila engkau bangun." 27

Kamu harus mengajarkan semuanya itu terus menerus kepada anak-anakmu dan bicarakanlah ketika kamu duduk di rumahmu, ketika kamu sedang dalam perjalanan, ketika kamu sedang berbaring, dan ketika kamu bangun. Orang tua Yahudi diberi tanggunggjawab untuk membesarkan dan merawat anak-anak mereka dan mengarahkan mereka kepada Firman Allah. Orang tua Yahudi mereka mengajarkan anaknya tentang hukum Allah. $^{28}$

Dengan demikian peran orang tua dalam pendidikan tidak bisa dipandang sebelah mata, terlebih keluarga Kristen dalam mengajarkan nilai-nilai iman kepada anaknya. Orang tua Kristen menginginkan suatu keyakinan yang mengarahkan pendidikan dan

${ }^{26}$ Robert E. Clark, Lin Johnson, Allyn K. Sloat, Christian Education: Foundations For The Future (Chicago: Moody Publishers, 1991), 597.

27 Alitab LAI.

${ }^{28}$ Michael J.Anthony (ed), Foundations

Of Ministry: an Introduction to Christian Education for a New Generation (Michigan: BakerAcademic, 1992), 389-390. 
membentuk anak-anak agar setia kepada Allah. ${ }^{29}$ Jelaslah bahwa keluarga zaman dahulu banyak fungsinya dan ikatan kekeluargaannya kuat. Sebaliknya, keluarga masa kini sudah banyak kehilangan fungsinya. Fungsi pendidikan sudah diserahkan pada lembaga-lembaga pendidikan seperti sekolah, sehingga banyak keluarga masa kini hanya sebagai konsumen pendidikan. ${ }^{30}$

Banyak model pendidikan yang dapat diterapkan untuk homeschooling, akan tetapi orang tua harus bijak memilih metode yang sesuai dengan gaya belajar anak. Model homeschooling sangat beragam mulai dari yang tidak terstruktur hingga yang sangat terstruktur. Model homeschooling yang tidak terstruktur adalah membiarkan anak-anak belajar apa saja sesuai minatnya dan orang tua tinggal mefasilitasinya, sedangkan model homeschooling yang sangat terstruktur adalah model belajar seperti sekolah regular, dengan menggunakan buku pegangan seperti sekolah, hanya saja belajarnya di rumah. ${ }^{31}$

Di Indonesia, jenis kegiatan homeschooling dibedakan atas (3) tiga format, yaitu:

\subsection{Homeschooling tunggal}

Homeschooling yang dilaksanakan oleh orang tua dalam suatu keluarga tanpa bergabung dengan yang lainnya. Biasanya homeschooling jenis ini diterapkan karena adanya tujuan atau alasan khusus yang tidak dapat diketahui atau dikompromikan dengan komunitas

${ }^{29}$ Richard J. Edlin, Hakekat Pendidikan Kristen (Jakarta: BPK Gunung Mulia, 2015), 55.

${ }^{30}$ Anita lie, Takim Andriono, Sarah Prasasti, Menjadi Sekolah Terbaik: PraktikPraktik Strategis Dalam Pendidikan (Jakarta: Tanoto Foundation, 2014), 162.

${ }^{31}$ Sumardiono, Ibid., 89. homeschooling yang lain atau karena lokasi dan tempat tinggal si pelaku homeschooling yang tidak memungkinkan berhubungan dengan komunitas homeschooling lain. ${ }^{32}$

\subsection{Homeschooling Majemuk}

Homeschooling yang dilaksanakan oleh dua atau lebih keluarga untuk kegiatan tertentu sementara kegiatan pokok tetap dilaksanakan oleh orang tua masing-masing. Alasannya, terdapat kebutuhan-kebutuhan yang dapat dikompromikan oleh beberapa keluarga untuk melakukan kegiatan bersama. Contohnya kurikulum dari kegiatan olahraga, seni/musik, sosial, dan keagamaan. $^{33}$

\subsection{Homeschooling Komunitas}

Gabungan beberapa homeschooling majemuk yang menentukan silabus, bahan pengajaran, kegiatan pokok seperti olah raga, seni, bahasa, sarana/prasarana dan jadwal pembelajaran. Dalam hal ini beberapa keluarga memberikan kepercayaan kepada Badan Tutorial untuk memberi materi pelajaran. Badan tutorial melakukan kunjungannya ke tempat yang disediakan komunitas. ${ }^{34}$

Adapun beberapa jenis pendekatan sekolah rumah menurut Imas Kurniasih ${ }^{35}$ dapat diidentifikasikan sebagai berikut:

1. School at-home approach adalah model pendidikan yang serupa dengan yang diselenggarakan di

${ }^{32}$ Seto Mulyadi. Homeschooling

Keluarga Kak Seto: mudah, meriah, dan direstui pemerintah (Bandung: PT. Mizan

Pustaka,2007),34.

33 Seto Mulyadi. Ibid., 35.

34 Seto Mulyadi. Ibid., 36.

${ }^{35}$ Imas Kurniasih, Homeschooling

(Jogyakarta : Penerbit Cakrawala, 2009), 28. 
sekolah. Hanya saja, tempatnya tidak di sekolah, tetapi di rumah. Metode ini juga sering disebut textbook approach, traditional approach, atau school approach.

2. Unit studies approach adalah model pendidikan yang berbasis pada tema. Pendekatan ini banyak dipakai oleh orang tua homeschooling. Dalam pendekatan ini, siswa tidak belajar satu mata pelajaran tertentu, tetapi mempelajari banyak mata pelajaran sekaligus melalui sebuah tema yang dipelajari. Metode ini berkembang atas pemikiran bahwa proses belajar seharusnya terintegrasi, bukan terpecah-pecah.

3. The Living Books approach adalah model pendidikan melalui pengalaman dunia nyata. Metode ini dikembangkan oleh Charlotte Mason. Pendekatannya dengan mengajarkan kebiasaan baik, keterampilan dasar seperti membaca, menulis, menghitung, serta mengekspose anak dengan pengalaman nyata, seperti study tour, mengunjungi museum, berbelanja ke pasar, mencari informasi di perpustakaan, menghadiri pameran, dan sebagainya.

4. The Classical approach adalah model pendidikan yang dikembangkan sejak abad pertengahan. Pendekatan ini menggunakan kurikulum yang distrukturkan berdasarkan tiga tahap perkembangan anak yang disebut Trivium. Penekanan metode ini adalah kemampuan ekspresi verbal dan tertulis. Pendekatannya berbasis teks/literatur (bukan gambar/image).

5. The Waldorf approach adalah model pendidikan yang dikembangkan oleh Rudolph Steiner, banyak ditetapkan di sekolah-sekolah alternatif Waldorf di Amerika. Karena Steiner berusaha menciptakan setting sekolah yang mirip keadaan rumah, metodenya mudah diadaptasi untuk homeschool.

6. The Montessori approach adalah model pendidikan yang dikembangkan oleh Dr. Maria Montessori. Pendekatan ini mendorong penyiapan lingkungan pendukung yang nyata dan alami, mengamati proses interaksi anakanak di lingkungan, serta terus menumbuhkan lingkungan sehingga anak-anak dapat mengembangkan potensinya, baik secara fisik, mental, maupun spiritual.

7. The Eclectic approach memberikan kesempatan pada keluarga untuk mendesain sendiri program homeschooling yang sesuai, dengan memilih atau menggabungkan dari sistem yang ada.

8. Unschooling approach berangkat dari keyakinan bahwa anak-anak memiliki keinginan natural untuk belajar dan jika keinginan itu difasilitasi dan dikenalkan dengan pengalaman di dunia nyata, maka mereka akan belajar lebih banyak daripada melalui metode lainnya.

9. Unschooling tidak berangkat dari textbook, tetapi dari minat anak yang difasilitasi. Model ini memiliki pandangan bahwa anak-anak memiliki keinginan natural untuk belajar, tidak berangkat dari textbook tetapi dari minat yang difasilitasi.

\section{Metode Penelitian}

Jenis penelitian yang digunakan dalam penelitian ini adalah metode penelitian kualitatif deskriptif. Metode penelitian kualitatif menurut Creswell dalam buku J.R. Raco, adalah suatu pendekatan atau penelusuran untuk mengeksplorasi dan memahami suatu 
gejala sentral. Untuk mengerti gejala tersebut, peneliti mewawancarai partisipan dengan mengajukan pertanyaan yang umum dan agak luas. Informasi yang disampaikan oleh partisipan kemudian dikumpulkan, ada yang berupa kata atau teks. Data yang berupa kata-kata atau teks tersebut kemudian dianalisis. Hasil analisis itu berupa penggambaran atau deskripsi atau dapat pula dalam bentuk tema-tema. Dari data-data itu, peneliti membuat interpretasi untuk menangkap arti yang terdalam. Hasil akhir dari penelitian kualitatif dituangkan dalam bentuk laporan tertulis. Laporan tersebut agak fleksibel. ${ }^{36}$

Adapun subjek penelitian ini adalah mereka yang terlibat secara langsung sebagai pelaku homeschooling yaitu: guru, siswa/i dan orang tua siswa/i di Wesley Pelita Bangsa school (WPBS) Pluit-Jakarta Utara. Populasinya adalah guru, siswa, dan orang tua sekolah Wesley Pelita Bangsa school (WPBS) Pluit- Jakarta Utara. Adapun jumlah populasinya adalah Guru berjumlah 7 orang, siswa berjumlah 20 orang, dan orang tua murid 40 orang jadi total populasi yang akan diteliti adalah 67 orang.

Dalam penelitian ini informanya menggunakan teknik purposive sampling (sampel bertujuan) karena untuk menentukan seorang menjadi sampel didasarkan pada tujuan tertentu. ${ }^{37}$ Purposive sampling yaitu informaninforman yang peneliti tentukan merupakan orang-orang yang menurut peneliti memiliki informasi yang dibutuhkan dalam penelitian ini, karena

\footnotetext{
36 J.R. Raco, Metode Penelitian

Kualitatif, Jenis, Karakteristik dan Keunggulannya (Jakarta: Grasindo, 2015), 7.

${ }^{37}$ Sugiyono, Metode Penelitian Administrasi..., 96.
}

informan terlibat secara langsung dengan permasalahan yang sedang diteliti. Adapun informan dalam penelitian ini adalah guru, siswa dan orang tua siswa Wesley Pelita Bangsa School (WPBS) Pluit-Jakarta Utara. Dengan demikian jumlah sampel dalam penelitian yang sesuai dengan kriteria di atas berjumlah 16 orang, dengan pembagian sebagai berikut: guru 4 orang, Orang tua siswa 6 orang, dan siswa-siswi 6 orang.

Adapun aktivitas dalam analisis data model Miles dan Huberman, sebagaimana dikutip oleh Sugiyono adalah:

1. Reduksi (data reduction). Mereduksi data berarti merangkum, memilih hal-hal pokok, memfokuskan pada hal-hal yang penting, dan dicari tema dan polanya.

2. Penyajian data (data display). Dalam penelitian kualitatif, penyajian data dapat dilakukan dalam bentuk uraian singkat, bagan dan hubungan antar kategori.

3. Verifikasi (conclusion drawing). Langkah ketiga dalam analisis data kualitatif menurut Miles dan Huberman adalah penarikan kesimpulan atau verifikasi. ${ }^{38}$

\section{Hasil Penelitian}

Dalam penelitian yang dilakukan oleh penulis ada beberapa hal yang menjadi penemuan penulis yaitu:

\subsection{Pemahaman Tentang \\ Homeschooling Di PKBM Wesley Pelita Bangsa School}

Dalam bagian ini, penulis menganalisis dua hal menyangkut pemahaman tentang homeschooling, yaitu pengertian homeschooling dan kurikulum. Menyangkut pengertian

\footnotetext{
${ }^{38}$ Sugiyono, Ibid 246.
} 
homeschooling, tampak bahwa pemahaman guru, orang tua dan siswa mengenai homeschooling cukup memadai. Homeschooling sebagai sekolah rumah dan juga sebagai sekolah pilihan alternatif bagi orang tua untuk memenuhi kebutuhan pendidikan anak. Homeschooling selalu identik dengan sekolah rumah tetapi sesuai dengan perkembangan pendidikan yang semakin cepat dan teknologi maka homeschooling tidak hanya dilakukan di rumah tetapi juga di sekolah. Homeschooling yang dilakukan di sekolah berupaya keras untuk membuat suasana belajar seperti di rumah sendiri mulai dari bentuk ruangan dan juga sarana dan prasarana lainnya sehingga siswa yang belajar di homeschooling merasa seperti di rumahnya sendiri.

Dalam konteks Indonesia, pendidikan homeschooling ini telah diakui oleh pemerintah sebagai bagian dari pendidikan nasional. Pendidikan sekolah rumah telah diatur dalam perundang-undangan yaitu pasal 1 undang-undang sistem pendidikan nasional (Sisdiknas No 20/2003). Dalam undang-undang tersebut, homeschooling dikategorikan dalam pendidikan keluarga dan lingkungan sebagai lingkup pendidikan informal yang berbentuk kegiatan belajar secara mandiri.

$$
\text { Meski hasil pendidikan }
$$

homeschooling telah diakui namun mengenai pengaturan standar isi dan proses pelayanan pendidikan homeschooling pemerintah tidak ikut terlibat. Dalam pasal 27 ayat 2 sendiri dinyatakan bahwa peserta didik dalam kegiatan homeschooling diakui layaknya bersekolah di pendidikan formal dengan syarat telah lulus ujian sesuai dengan standar nasional pendidikan. Dalam hal ini adalah ujian penyetaraan paket $\mathrm{C}$ untuk tingkat SMA.
Berdasarkan arti dari pendidikan dan sistem pendidikan nasional pada pasal 1 UU nomor 20 tahun 2003 tentang Sisdiknas, maka sekolah rumah atau homeschooling ini sudah mewakilinya. Homeschooling sudah bisa memenuhi tujuan pendidikan nasional yaitu mencerdaskan kehidupan bangsa. Pada akhirnya homeschooling ini akan menjadi sebuah pilihan lain atau alternatif pendidikan bagi siswa dan orang tuanya. Dengan homeschooling anak akan tumbuh berkembang dengan pembelajaran yang terkontrol oleh orang tuanya. Apabila orang tua dan anak merasa atau melihat kekecewaan pada kondisi pendidikan di luar, maka homeschooling ini bisa menjadi solusi atau pembelajaran alternatif.

Adapun kurikulum yang digunakan di PKBM Wesley Pelita Bangsa School (WPBS) adalah Accelerated Christian Education (ACE). Kurikulum ini dibeli dari sebuah perusahaan Amerika yang menghasilkan kurikulum Pendidikan Kristen. Kurikulum sekolah yang disusun berdasarkan interpretasi literal dari Alkitab dan yang mengajarkan mata pelajaran akademik lainnya dari sudut pandang Protestan fundamentalis. Didirikan pada tahun 1970 oleh Donald dan Esther Howard, situs web Accelerated Christian Education (ACE) menyatakan bahwa ini digunakan di lebih dari 6.000 sekolah di 145 negara. ${ }^{39}$ Ada beberapa alasan mengapa sekolah ini menggunakan kurikulum tersebut, yaitu: (1) kurikulum berstandar internasional; (2) Fleksibel, artinya bisa dipakai dalam satu ruangan dengan level kelas yang berbeda atau tingkat yang berbeda; (3) Lulusannya lebih mudah

\footnotetext{
${ }^{39}$ https://en.wikipedia.org/wiki/Accelerate d_Christian_Education.
} 
diterima di universitas luar negeri karena kurikulum ini berstandar internasional; (4) Bahasa Inggrisnya mudah dipahami; (5) Penulisnya berasal dari lembaga Kristen; (6) Kurikulum ini berbasis Alkitab dan sesuai visi misi sekolah untuk membangun iman dan menanamkan iman kristiani; (7) Materinya mengarah pada nilai-nilai kehidupan kekristenan. Meski demikian, tetap saja ada kelemahan dari kurikulum Accelerated Christian Education (ACE) ini, yaitu: tidak terintegrasi dengan sistem pendidikan di Indonesia, tidak memiliki mata pelajaran bahasa Indonesia, dan lulusannya tidak bisa masuk universitas di Indonesia jika tidak mengikuti ujian penyetaraan paket $\mathrm{C}$ (setara SMA).

\subsection{Pemahaman tentang Model Homeschooling di PKBM Wesley Pelita Bangsa School (WPBS)}

Pemahaman guru, orang tua dan siswa/i tentang model homeschooling cukup baik namun mereka hanya mengetahui dua model homeschooling yaitu homeschooling tunggal dan homeschooling majemuk. Adapun kosenkuesinyan adalah mereka tidak bisa memilih model homeschooling yang sesuai dengan ketubuhan dan karekter anaknya. Pemilihan model homeschooling harus berdasarkan pada kebutuhan dan minat anak sehingga mudah untuk mengikuti kegiatan belajar dalam sistim homeschooling. Sementara model homeschooling yang dikemukakan oleh Sumardiono ada tiga model yaitu homeschooling tunggal, homeschooling Majemuk dan homeschooling Komunita (bnd. Bab II hal. 22). Hal ini dikarenakan guru, orang tua tidak memiliki latar belakang pendidikan tentang homeschooling. Bisa juga karena kurangnya informasi dan buku-buku tentang homeschooling yang memadai sehingga membuat informasi tentang homeschooling terkendala. Untuk mengatasi hal tersebut maka perlu seminar nasional untuk guru dan orang tua sehingga dengan memahami model homeschooling semakin banyak pilihan alternatif untuk menyekolahkan anak.

Sepatutnya guru yang mengajar di homeschooling mengetahui modelmodel homeschooling yang sedang berkembang saat ini sehingga mampu menguasai model-model homeschooling serta mudah untuk memberi informasi bagi orang yang membutuhkan penjelasan tentang homeschooling serta bisa memilih model yang cocok buat peserta didiknya. Untuk mencapai tahap pengenalan model-model homeschooling maka pihak sekolah harus berperan aktif memberikan seminar atau pelatihan kepada guru dan orang tua.

\subsection{Pemahaman tentang penggunaan model homeschooling dalam pembelajaran PAK di PKBM Wesley Pelita Bangsa School}

Penggunaan model homeschooling dalam pembelajaran PAK di PKBM Wesley Pelita Bangsa School (WPBS) sangat ditekankan dalam proses pembelajaran, siswa diarahkan untuk belajar secara mandiri. Menggunakan kurikulum Bible Old Testament Survey (BOTS) dan Bible New Testament survey (BNTS). Kurikulum PAK ini sangat bagus karena membahas Alkitab mulai dari kejadian sampai Wahyu. Isi kurikulumnya yaitu pengantar tiap kitab, sejarah, kisah-kisah dalam Alkitab, dan memuat test tertulis. Menanamkan nilainilai PAK kepada siswa/i dengan membentuk kelompok sel, ibadah bersama setiap hari Kamis, dengan harapan bahwa siswa mempererat hubungannya dengan Tuhan. Hal ini 
sama dengan pandangan Thomas Groome tentang tujuan PAK adalah membimbing anak ke dalam pengenalan iman Kristen.

Sebagai contoh, penulis memberikan gambaran tentang kurikulum Bible Old Testament Survey (BOTS) yang digunakan untuk level 1 atau SMA kelas 1 yang dibelajarkan dalam semester dua. Kurikulum ini diberi kode nomor 120 yang artinya kurikulum ini dimaksudkan untuk pelajaran PAK. Buku Kurikulum ini terdiri dari pegangan guru dan siswa. Pada bagian siswa, di dalam buku tersebut terdapat pengantar mengenai kitab-kitab Perjanjian Lama, yaitu: Daniel, Hosea, Yoel, Amos, Obaja, Yunus, Mikha, Nahum, Habakuk, Zefanya, Hagai, Zakharia, dan Maleakhi. Setelah uraian pengantar pada masingmasing kitab, diberikan pertanyaanpertanyaan berkisar 40-50 butir pertanyaan yang harus dijawab siswa. Buku pegangan guru memuat jawaban atas pertanyaan-pertanyaan tersebut. Dalam penelitian ini, penulis tidak mendapatkan ijin untuk melihat isi buku tersebut karena bersifat rahasia. Buku kurikulum ini diberlakukan secara terusmenerus. Model pembelajaran ini jarang direvisi jika melihat tahun terbit pertama adalah tahun 1974 dan baru mengalami revisi tahun 1996.

\section{Untuk kurikulum Bible New} Testament Survey (BNTS), contoh penyajiannya memuat tujuan pembelajaran, kosakata, catatan, kitab Wahyu (para penulis, waktu dan tempat penulisan, kekhasan, tujuan, masalahmasalah, ditulis kepada siapa, dan rencana), proyek dan Tes tertulis. Setelah uraian tersebut, diberikan pertanyaan-pertanyaan berkisar 20-25 butir pertanyaan yang harus dijawab siswa. Buku kurikulum ini diberlakukan secara terus-menerus. Model pembelajaran ini jarang direvisi jika melihat tahun terbit pertama adalah tahun 1974 dan baru mengalami revisi tahun 1996.

Menurut penulis, kurikulum yang bagus itu sebaiknya memiliki beberapa aspek, diantaranya mengarah pada minat dan bakat karena setiap anak tentunya memiliki minat dan bakat terhadap suatu hal. Setiap guru tentunya berpatokan pada suatu kurikulum, apabila kurikulum tersebut mengarahkan anak pada minat dan bakat, otomatis guru yang akan menjadi orang terdekat siswa akan mengarahkan siswa sesuai dengan minat dan bakat siswa. Selanjutnya, kurikulum yang baik adalah yang tidak mengekang, artinya jangan sampai siswa merasa terkekang karena guru mereka berada di posisi sebagai peran utama, sangat kuat, dan tadak bisa dibantah. Apabila hal tersebut terjadi akan mengakibatkan siswa menjadi tidak berani mengeluarkan pendapat mereka dan tidak menanamkan jiwa kritis pada siswa. Dalam buku ilmu aplikasi pendidikan menyatakan bahwa salah satu prinsip dasar dalam pengembangan kurikulum adalah fleksibilitas, yaitu kelenturan kurikulum melayani perbedaan kemampuan, minat dan kebutuhan peserta didik dan pengguna. ${ }^{40}$ Dalam melaksanakan kurikulum ini, pertama-tama siswa berdoa selama 5 menit, menghafal ayat yang ada di buku 5 menit, diteruskan dengan proses belajar mengajar 90 menit, setelah itu siswa mengerjakan tes tertulis selama 30 menit. Peran guru di sini hanya mengawasi dan menunggu siswa jika ada pertanyaan.

\footnotetext{
${ }^{40}$ Tim Pengembang Ilmu Pendidikan
} FIP-UPI, Ilmu dan Aplikasi pendidikan: Bagian 2 Ilmu Pendidikan Praktis (Bandung: Grasindo, 2007)120. 
Menurut penulis pelaksanaan belajar di kelas cukup bagus di mana siswa memiliki kontrol penuh untuk dirinya sendiri. Kegiatan belajar mengajar agak berbeda dengan di sekolah. Guru lebih berperan sebagai fasilitator. Tujuan pendidikan agar siswa cinta belajar. Namun ada kelemahan dalam proses belajar seperti ini yaitu jika siswanya malas dan tidak mau belajar maka yang terjadi adalah dia tidak bisa menyelesaikan materi yang harus dia kerjakan hari itu. Di sinilah guru memiliki peran untuk melihat apakah siswa benar-benar belajar atau sedang bermain-main dengan bukunya.

\section{Kesimpulan}

Pengertian Homeschooling di PKBM Wesley Pelita Bangsa School (WPBS) adalah sekolah alternatif yang bisa dilakukan di rumah dan di sekolah.

1. Model homeschooling di PKBM Wesley Pelita Bangsa School (WPBS) adalah menggunakan model homeschooling Komunitas. Keunggulan dari homeschooling di PKBM Wesley Pelita Bangsa School (WPBS) adalah lebih fokus pada individu. Anak-anak memulai pelajaran pada tingkat yang sesuai dengan kebutuhan mereka dan sesuai dengan tingkat kemampuan mereka juga.

2. Penggunaan model homeschooling dalam pembelajaran PAK di PKBM Wesley Pelita Bangsa School (WPBS) adalah menggunakan model homeschooling komunitas yang lebih fokus pada individu. Tempatnya di sekolah dan pengajarnya adalah guru PAK. Adapun kurikulum yang dipakai adalah Bible Old Testament Survey (BOTS) dan Bible New Testament Survey (BNTS).

\section{Daftar Pustaka}

. Apa itu Homeschooling, 35

Gagasan Pendidikan Berbasis

Keluarga. Jakarta: PandaMedia, 2014.

. Ilmu dan Aplikasi Pendidikan,

bagian 3 ilmu pendidikan teoritis.

Bandung: Garsindo, 2007.

. Ilmu dan Aplikasi Pendidikan:

bagian 2 Ilmu Pendidikan Praktis.

Bangung: Garsindo, 2007.

Membesarkan Anak dengan

Kreatif. Yogyakarta: Andi, 2012.

. Psikologi praktis: Anak, Remaja,

dan Keluarga. Jakarta: BPK Gunung

Mulia, 2004.

Alkitab, Lembaga Alkitab Indonesia.

Anthony, Michael J. (ed), Foundations of Ministry: an Introduction to Christian Education for a New Generation. Michigan: BakerAcademic, 1992.

Asmani, Ma'mur Jamal. Buku Pinter Homeschooling: Menjadi Kegiatan Belajar Lebih Nyaman dan Mengena. Jogjakarta: FlashBooks, 2012.

Clark, Robert E., Lin Johnson, Allyn K. Sloat. Christian Education:

Foundations For The Future. Chicago: Moody Publishers, 1991.

Edlin, Richard J. Hakekat Pendidikan Kristen. Jakarta: BPK Gunung Mulia, 2015.

Groome, Thomas H. Christian Religious Education-Pendidikan Agama Kristen: Berbagi Cerita dan Visi Kita. Jakarta: BPK. Gunung Mulia, 2010.

Gunarsa,Yulia Singgih D. Psikologi Untuk Keluarga. Jakarta: BPK Gunung Mulia, 2012.

Kurniasih, Imas. Homeschooling. Yogyakarta: Cakrawala, 2009.

Lie, Anita, dkk. Menjadi Sekolah Terbaik: Praktik-Praktik Strategis Dalam

Pendidikan. Jakarta: Tanoto Foundation, 2014.

Mulyadi, Seto. Homeschooling Keluarga Kak Seto: mudah, meriah, dan 
direstui pemerintah. Bandung: PT. Mizan Pustaka, 2007.

Novita, Windya. Serba-serbi Anak: Yang Perlu Diketahui Seputar Anak dari dalam Kandungan Hingga Masa Sekolah. Jakarta: Gramedia, 2007.

Raco, J.R. Metode Penelitian Kualitatif, Jenis, Karakteristik dan Keunggulannya. Jakarta: Grasindo, 2015.

Setyowati Sie, Holy. Homeschooling Creating The Best of Me. Jakarta: Kompas Gramedia, 2010.

Sumardiono. Homeschooling A Leap for better Learning, Lompatan Cara Belajar. Jakarta: Gramedia, 2007.

Tim Pengembang Ilmu Pendidikan FIP-UPI. Ilmu dan Aplikasi Pendidikan, bagian 4 pendidikan lintas bidang. Bangung: Garsindo, 2009.

Undang-Undang Republik Indonesia Nomor 20 Tahun 2003 Tentang Sistem Pendidikan Nasional.

\section{Jurnal}

Dwi R, Mutiara. Belajar tidak harus di Sekolah formal, Tabloid Mom \& Kiddie, edisi 14, tahun 1, 12-25 Maret 2007.

hthttps://en.wikipedia.org/wiki/Accele rated_C 
